\title{
Psykiatrirevolusjonen i 1960-årene - noe igjen av resultatene?
}

\author{
Da det første «terapeutiske samfunn» i Norge ble innført, var det begynnelsen på en revolusjon i norsk psykia- \\ tri. I hvilken grad har prinsippene for denne grunnleggende behandlingsendringen overlevd i dagens psykiatri?
}

Det såkalte terapeutiske samfunn, som først ble utviklet i engelsk og amerikansk psykiatri, innebar en grunnleggende forandring av institusjonsbehandling ved psykoser, alvorlige personlighetsforstyrrelser og rusmisbruk. I Norge ble slik behandling etablert ved Ullevål og Dikemark sykehus og påvirket også den øvrige psykiatrien. I denne artikkelen drøfter jeg i hvilken grad prinsippene for det terapeutiske samfunn har overlevd i dagens psykiatri.

Da overlege Herluf Thomstad (19052000) i 1959 innførte det første «terapeutiske samfunn» i Norge, var bakgrunnen en økende interesse for psykodynamisk psykoterapi og gruppetilnærming og en kritisk holdning til akademisk psykiatris vekt på diagnoser, biologi og epidemiologi.

I England hadde psykiateren Thomas Main (1911-90) gjort om en tradisjonell psykiatrisk institusjon til et terapeutisk samfunn, og Maxwell Jones (1920-2015) hadde utviklet et slikt behandlingsprogram for alvorlige personlighetsforstyrrelser (1). Thomstads forgjenger, Trygve Braatøy (1904-53), hadde skrevet en knusende kritikk av legens muligheter til å hjelpe sine pasienter psykoterapeutisk (2).

I norsk psykiatri hadde bare legene og psykologene vært «terapeuter», mens sykepleiere, hjelpepleiere, fysioterapeuter og ergoterapeuter var «pleiere» som skulle gi omsorg og aktivisere pasientene. Pasientene derimot var passive mottakere. I det terapeutiske samfunn ble rollefordelingen og behandlingen grunnleggende endret og i stor grad basert på psykodynamisk og sosialpsykologisk tenkning (3). Pasientene selv og alt personale - fra overlegen til pleiemedhjelperne - ble nå terapeuter. De hvite frakkene ble fjernet, og hierarkiet snudd. Avdelingsoverlegen var fremdeles øverst, men deretter kom pasientene, og så de øvrige ansatte. For første gang i norsk psykiatri fikk pasienten en stemme.

I rendyrket form ble det terapeutiske samfunn bare etablert ved Ullevål og Dikemark sykehus. Man oppfattet psykiske lidelser først og fremst som uttrykk for et samspillsproblem, et relasjonsproblem. Avdelingene ble derfor organisert slik at samspillsproblemene kunne vise seg og bli bearbeidet i grupper døgnet rundt. Pasientene fikk også systematisk psykodynamisk psykoterapi. Det radikalt nye var at dette gjaldt både psykotiske og ikke-psykotiske pasienter. Behandlingen resten av døgnet sto miljøterapeutene for. Hver morgen møttes alle til et fellesmøte med opptil 100 deltagere, ledet av en pasient. Døgnrapporten fra den enkelte gruppe ble lest av en pasient. Familien ble trukket med $\mathrm{i}$ hele behandlingen. Ved utskrivning ble pasienten fulgt opp poliklinisk av sin psykoterapeut. Ettervernet ble høyt prioritert.

Tankegangen ble initialt møtt med til dels sterk motstand i resten av psykiatrien, særlig mot at pasienten fikk innflytelse på egen og andre pasienters behandling, fjerningen av de hvite frakkene, og den flate

\section{«For første gang i norsk psykiatri fikk pasienten en stemme»}

strukturen som ble beskyldt for å være «pseudodemokratisk». Likevel etablerte snart den øvrige psykiatrien også elementer av det terapeutiske samfunn: tverrfaglige team, miljøterapi og psykoterapi til flere. De hvite frakkene forble hengende i skapet.

Omfattende forskning fra Norge viste at det terapeutiske samfunn hadde klart bedre effekt enn vanlig institusjonsbehandling på forløpet av symptomatologi, rusmisbruk og sosial fungering (4-9).

I forskningen dokumenterte man imidlertid også at den opprinnelige modellen ikke passet for alle typer pasienter. En versjon med færre gruppemøter kombinert med individuell psykoterapi hadde meget god effekt for psykotiske og nærpsykotiske pasienter med og uten rusmisbruk. For pasienter med personlighetsforstyrrelse med og uten rusmisbruk var den opprinnelige modellen svært velegnet $(4,7)$.

\section{Hva ble igjen?}

Utover 1980-årene ble omfanget og varigheten av institusjonsbehandling redusert. Det terapeutiske samfunn forutsatte en heldøgns behandling, og de fleste prinsippene gjenfinnes derfor i dag bare i kollektiver for rusmisbrukere og dagavdelinger for behandling av personlighetsforstyrrelser. I den øvrige psykiatrien fortsatte man med miljøterapi og tverrfaglige team, men institusjonsoppholdene ble korte fordi sengeantallet ble betydelig redusert. Både heldøgnsenheter og polikliniske DPS har dessuten vært gjennom en omfattende omstilling, med økende krav om raskere behandling, redusert sekretær- assistanse og omfattende rapportering. Er det noe igjen av elementene til det terapeutiske samfunn i dagens psykiatri?

Ved døgnavdelinger og poliklinikker får nå pasienters relasjonsproblemer, livssituasjon og ubevisste irrasjonelle personlighetsfaktorer etter min mening generelt mindre oppmerksomhet til fordel for utredninger, biologiske behandlingsmetoder og et ensidig symptomfokus. Det er lite rom for både korttids psykoterapi og langvarig oppfølging med innsiktsøkende eller støttende psykodynamisk psykoterapi.

Den behandlingstiden som vi vet at pasienter med moderate og alvorlige psykiske lidelser trenger for å bli varig hjulpet, er etter min erfaring kraftig redusert. Effekten av en stabil pasient-terapeut-relasjon over lang tid kan ikke fullt ut utnyttes. Rommet for å utøve systematisk psykoterapi og sosialpsykiatrisk ettervern blir stadig mindre.

Den betydningsfulle rollen pasientene spilte i det terapeutiske samfunn, er også forsvunnet. Der brukermedvirkning var selvsagt, må nå pasienter organisere seg i pasientforeninger for å bli hørt. Et systematisk samarbeid med familiene, satsing på å endre en utålelig livssituasjon og poliklinisk oppfølging av samme terapeut som under institusjonsoppholdet, er omtrent fraværende. Tanken bak å jobbe tverrfaglig var at hver enkelt faggruppe skulle bidra med sin unike kompetanse. Nå gjør alle nesten det samme uansett faglig bakgrunn, noe som etter min mening tar mye tid og hindrer videreutviklingen av den enkeltes spesialkompetanse.

Myndighetene ønsker at vi skal gjøre stadig flere pasienter friske og velfungerende til uforandret kostnad. Men pasientenes psykiske lidelser er uforandrede og dermed også deres behov for behandlernes tid og innsats. Det er derfor en fare for at vi terapeuter i stadig mindre grad kan oppleve at behandlingen vi gir, utgjør en forskjell for pasientene. Det kan føre til at vi blir mer kyniske.

Det er svært tankevekkende at de nye medikamentfrie tilbudene som nå etablereres (10), får ressurser til å kunne bruke de fleste elementene fra det terapeutiske samfunn, som familie- og nettverksarbeid, ulike psykoterapeutiske metoder, fysioterapi, miljøterapi og pasienters medvirkende posisjon. De pasienter som får medikamentell behandling for sin psykose eller bipolare lidelse, trenger naturligvis akkurat det samme bio- 
psykososiale hjelpeprogrammet. Noe annet ville være en skandale.

Det terapeutiske samfunn sto for et fellesskap mellom pasienter, familier, behandlere og samfunnet. Det er snart bare en ruin tilbake. Tiden er kanskje inne for en ny revolusjon. Er det pasientene som må gå i spissen for denne?

\section{Per Vaglum}

per.vaglum@medisin.uio.no

Per Vaglum er psykiater og professor emeritus ved Avdeling for medisinsk atferdsvitenskap, Det medisinske fakultet, Universitetet i Oslo. Forfatter har fylt ut ICMJE-skjemaet og oppgir ingen interessekonflikter.

\section{Litteratur}

1. Albretsen CS. Grunnleggeren av det første terapeutiske samfunn i norsk psykiatri. Tidsskr Nor Laegeforen 2002; 122: 2000-1.

2. Braatøy T. Pasienten og legen. Oslo: Cappelen, 1952.

3. Haugsgjerd S, Jörstad J, Ostberg B et al. 1000 ord om det terapeutiske samfunn. Nord Med 1972; 87 49-50.

4. Vaglum P. Unge stoffmisbrukere i et terapeutisk samfunn. Oslo: Universitetsforlaget, 1979.

5. Friis S. Hva slags postatmosfære er terapeutisk for psykotiske og for ikke-psykotiske pasienter? Om nødvendigheten av å differensiere behandlingsmiljøer. Tidsskr Nor Laegeforen 1981; 101 . 848-52.

6. Vaglum P. Friis S, Jørstad J et al. From a panacea to a special treatment method. International Jour nal of Therapeutic Communities 1982; 3: 24-32.

7. Vaglum $P, B ø e$ L. Individorientert eller gruppeorientert miliøterapi for schizofrene? - En kvasieksperimentell undersøkelse fra et terapeutisk samfunn. I: Vaglum P. Karterud S, Jørstad J (red.) Institusjonsbehandling i moderne psykiatri. Oslo: Universitetsforlaget, 1984: 24-36.

8. Vaglum P. Friis S, Karterud S. Kan det terapeutiske samfunn forandres så det passer bedre for pasienter og personale i dagens psykiatri? Nord Psykiatr Tidsskr 1985; 39: 69-74.

9. Karterud S. Group processes in therapeutic communities. Doktorgradsavhandling. Oslo: Universitetet i Oslo, 1989.

10. Gros L. Helse Nord oppretter medikamentfritt døgntilbud innen psykisk helse. Helse-nord.no. https://helse-nord.no/nyheter/helse-nordoppretter-medikamentfritt-dogntilbud-innenpsykisk-helse (18.4.2017).

Mottatt 5.4. 2017, første revisjon innsendt 13.4 2017, godkjent 18.4. 2017. Redaktør: Ketil Slagstad.

Publisert først på nett. 